\title{
PEMBERDAYAAN POTENSI MASYARAKAT DAN KELUARGA SEBAGAI UPAYA PERBAIKAN GIZI ANAK BALITA
}

\section{PENDAHULUAN}

Gizi merupakan bagian penting yang mendapat perhatian serius dari pemerintah. Tingkat keadaan gizi optimal akan tercapai apabila kebutuhan gizi itu terpenuhi, mulai dari pemberian asupan pada usia balita. Masalah gizi terjadi di setiap siklus kehidupan, dimulai sejak dalam kandungan (janin), bayi, anak, dewasa, dan usia lanjut. Periode dua tahun pertama kehidupan merupakan masa kritis, karena pada masa ini terjadi pertumbuhan dan perkembangan yang sangat pesat. Melihat tingginya angka gizi buruk di Indonesia pemerintah membutuhkan alternatif kebijakan guna menanggulangi masalah tingginya angka gizi buruk. Salah satu langkah strategi yang dilakukan pemerintah untuk menanggulangi masalah angka gizi buruk adalah dengan menerapkan Perbaikan Gizi Masyarakat dalam upaya menuntaskan Gizi Buruk. (Nugroho et al., 2020)

Status gizi pada balita sangat penting untuk diperhatikan karena akan mempengaruhi perkembangan dan pertumbuhan balita. gizi kurang pada balita masih banyak dijumpai dan penyebab nya bisa disebabkan karena kurang nya pengetahuan ibu balita tentang gizi. sehingga ibu balita tidak memberikan makanan sesuai dengan kebutuhan gizi untuk balita, seringkali disamakan dengan makanan orang dewasa. Selain kurangnya pengetahuan masalah gizi disebabkan karena status ekonomi keluarga dan kecukupan pangan didaerah tersebut. (Jayani., 2015)

Banyak negara di dunia mengalami permasalahan gizi ganda yaitu stuntig, wasting, dan overweight pada anak balita, dan indonesia termasuk salah satunya. Berdasarkan Global Nutrition Report tahun 2014, indonsia merupakan negara dengan urutan ke-17 dari 117 negara yang memiliki masalah gizi kompleks stunting, wasting, dan overweight. Hal ini terbukti dengan masih tingginya prevelensi masalah gizi kurang (19,6\%), stunting (37,2\%) dan semakin meningkatnya kegemukan pada balita $(11,8 \%)$. Masalah kurang gizi pada anak bermula dari kurang gizi saat kehamilan yang mengakibatkan kemampuan kognitif yang rendah, beresiko stanting, serta pada usia dewasa beresiko menderita penyakit kronis. Masalah gizi jika tidak di 
tangani akan menimbulkan masalah yang lebih besar, bangsa indonesia dapat mengalami lost generation. (Rosha et al., 2016).

\section{UPAYA PERBAIKAN GIZI BALITA}

Karbohidrat memberikan asupan 60-75\% dari jumlah energi total. Satu gram karbohidrat mengandung 4,1 kalori. Berdasarkan hasil analisis karbohidrat dari $100 \mathrm{~g}$ roti rumput laut lawi-lawi (Ceulerpa ra-cemosa) substitusi tempe menunjukkan bahwa kadar karbohidrat tertinggi pada perlakuan 1: 3 (25\% rumput laut lawi-lawi dan 75\% tempe) sebesar $56,10 \%$. Hal ini dikarenakan gabungan dari karbohidrat kompleks yang ada pada rumput laut lawilawi dan karbohidrat sederhana yang ada pada tempe pada formulasi ini menghasilkan kandungan karbohidrat total yang tinggi. Kandungan karbohidrat terendah pada perlakuan 1:0 (100\% rumput laut lawi- lawi) sebesar 48,96\%. (Syarfaini dkk., 2019)

Adapun Ubi Jalar Ungu ( Impomea Batatas L. Poiret) merupakan salah satu jenis ubi jalan yang mulai banyak mendapat perhatian belakangan ini. bahan opangan ini mulai banyak diminati masyarakat karena selain mempunyai komposisi gizi yang baik juga memiliki fungsi fisiologis tettentu bagi tubuh. Ubi jalar ungu merupakan sumber vitamin dan mineral, vitamin yang terkandung dalam ubi jalar antara lain vitamin A, vitamin C, vitamin B1 dan rivolvavin. Sedangkan mineral dalam ubi jalar ungu di antaranya adalah zat besi $(\mathrm{Fe})$, fosfor $(\mathrm{P})$, dan kalsium (Ca). Kandungan lainnya adalah protein lemak, serat kasar dan abu ( Amriani, 2017).

\section{HUBUNGAN PERSONAL HYGIENE PEMBERIAN SUSU FORMULA DENGAN KEJADIAN DIARE PADA BAYI ATAUPUN BALITA}

Diare merupakan salah satu penyakit menular melalui air yang menjadi masalah utama di negara-negara berkembang termasuk indonesia. Diare pada umumnya disebabkan oleh kualitas hygiene dan sanitasi lingkungan yang masih belum memenuhi persyaratan. Usia bayi dan balita menjadi usia yang rentan terhadap penyakit diare. Penyakit ini termasuk penyakit menular yang di tandai dengan gejala-gejala seperti : perubahan bentuk dan konsistensi tinja menjadi lembek sampai mencair dan bertambahnya frekuensi buang air besar lebih dari biasanya (3 kali atau lebih dalam sehari) di sertai muntah-muntah, sehingga penderita mengalami kekurangan cairan tubuh (dehidrasi) yang pada akhrirnya apabila tidak mendapat pengobatan segera dapat menyebabkan kematian. (Shidi, 2016)

Menurut hasil riskesdas Tahun 2013, insiden penyakit diare pada balita adakah 17,0\%, CFR kejadian luar biasa (KLB) diare di indonesia pada tahun 2011 adalah 0,29\% meningkat menjadi 2,06\% di tahun 2012 lalu mengalami penurunan di tahun 2013 menjadi 1,08\%. 
Sedangkan pada tahun 2013 sulawesi selatan ada pada perinkat ketiga setelah Paoua dan NTT yaitu 10,2\% balita yang penderita diare. (Alam dan Syahrir, 2017).

Pemberian susu formula pada bayi dengan cara yang tidak tepat dapat menimbulkan bahaya kesehatan, terutama diare pada bayi maupun balita. Susu formuka menjadi media yang baik bagi pertumbuhan bakteri, jamur dan sebagainya. Jenis bakteri yang bisa di temukan pada susu formula adalah bakteri coliform. Susu firmula lebih muda terkontaminasi bakteri di sebabkan oleh botol yang tidak higenis. Hal ini di pengaruhi oleh perilaku Hidup bersih Sehat (PHBS) ibu. Oleh karena itu perlu diperhatikan pada saat persiapan dan pemberian susu, harus dilakukan hal-hal seperti menjaga kebersihan botol susu, menjaga botol susu tetap kering sebelum di gunakan, mencuci botol susu menggunakan sabun yang aman untuk bayi. Menggunakan alat khusus botol susu, memberihkan semua bagian botol, membilas dengan air mengalir, dan mensterilkan botol susu, sehinggadapat mengurangi terjadinya kontaminsi. (Kasasiah \& Hendiana, 2020).

Menurut Winarno (2011), ada beberapa faktor yang mempengaruhi keberhasilan pemberian susu formula yaitu : peralatan makanan yang digunakan harus dalam keadaan bersih, serta cara pemberian susu formula harus disesuaikan dengan takaran, selain itu, waktu pemberian susu pada bayi atau balita perlu di perpendek. Lebih baik di buatkan susu berkalikali dengan cara steril. Mempersiapkan susu dengan cara yang benar, yaitu di didihkan, setelah itu didinginkan hingga suhunya sekitar 70 derajat $\mathrm{C}$, baru kemudian di campurkan dengan susu formula. Bakteri yang akan mati pada suhu di atas 60 derajat $\mathrm{C}$ meskipun berakibat kehilangan dan kerusakan zat gizi pada susu formula.

Pemberian susu formula di sarankan tidak di gunakan kecuali idikasi tertentu atau dalam keadaan terpaksa. Mungkin sebaikan harus berusaha agar tetap menggunakan ASI eksklusif sampai berumur 6 bulan dan melanjutkan pemberian ASI sampain umur 2 tahun. Selain itu juga bagi pengelola program gizi puskesmas kenali besar, di harapkan dapat menggiatkan kembali kegiatan posyandu dan memberikan penyuluhan mengenai pentingnya ASI eksklusif. ( Astari \& kusumastuti, 2013). 
Secara nasional cakupan pemberian ASI eksklusif di indonesia berfluktuasi selama 3 tahun terkahir. Cakupan pemberian ASI eksklusif pada bayi 0-5 bulan turun dari 62,2\% tahun 2007 menjadi 56,2\% pada tahun 2008. Namun meningkat lagi pada tahun 2009 menjadi 61,3\%. Sedangkan cakupan pemberian ASI eksklusif papda bayi sampai 6 bulan turun dari $28,6 \%$ pada 2007 menjadi 24,3\% pada tahun 2008 dan naik lagi menjadi 34,3\% pada tahun 2009. Alasan yang menjadi penyebab kegagalan praktek ASI eksklusif bermacam macam seperti budaya memberika makanan pralaktal, memberikan tambahan susu formula karena ASI tidak keluar, menghentikan pemberian ASI karena bayi atau ibu sakit, ibu harus bekerja, dan ibu ingin mencoba susu formula. (Ramdhani dkk., 2013) 


\section{DAFTAR PUSTAKA}

Alam, S., \& Syahrir, S. (2017). Hubungan Personal Hygiene Pemberian Susu Formula Dengan Kejadian Diare Pada Bayi di Kelurahan Dannuang Kecamatan Ujung Loe Kabupaten Bulukumba Tahun 2016. HIGIENE: Jurnal Kesehatan Lingkungan, 3(2), 76-86.

Amriani, A. (2017). Analisis Kandungan Zat Gizi Biskuit Ubi Jalar Ungu (Ipomoea Batatas L. Poiret) sebagai Alternatif Perbaikan Gizi di Masyarakat (Doctoral dissertation, Universitas Islam Negeri Alauddin Makassar).

Astari, N., \& Kusumastuti, A. C. (2013). Hubungan Pemberian Susu Formula Dengan Kejadian Diare Pada Bayi Usia 0-6 Bulan. Journal of Nutrition College, 2(4), 419-424.

Jayani, I. (2015). Hubungan kesadaran gizi keluarga dengan status gizi pada balita di Desa Sidoarjo Kecamatan Jambon Kabupaten Ponorogo. Care: Jurnal Ilmiah Ilmu Kesehatan, 3(3), 45-54.

Kasasiah, A., \& Hendiana, S. N. A. (2020). Kejadian Diare pada Balita di Desa Karyasari Kecamatan Rengasdengklok Kabupaten Karawang dan Kaitannya dengan Pemberian Susu Formula. PharmaCine: Journal of Pharmacy, Medical and Health Science, 1(1), 9-15.

Nugroho, E. E., Mahsyar, A., \& Usman, J. (2020). Implemetasi Kebijakan Dinas Kesehatan Dalam Penanganan Gizi Buruk Pada Balita Di Kabupaten Enrekang. Kajian Ilmiah Mahasiswa Administrasi Publik, 1(2), 700-714.

Rosha, B. C., Sari, K., SP, I. Y., Amaliah, N., \& Utami, N. H. (2016). Peran intervensi gizi spesifik dan sensitif dalam perbaikan masalah gizi balita di Kota Bogor. Buletin Penelitian Kesehatan, 44(2), 127-138.

Rahmadhani, E. P., Lubis, G., \& Edison, E. (2013). Hubungan pemberian ASI eksklusif dengan angka kejadian diare akut pada bayi usia 0-1 tahun di Puskesmas Kuranji Kota Padang. Jurnal Kesehatan Andalas, 2(2), 62-66.

Syarfaini, S., Damayati, D. S., Susilawaty, A., Alam, S., \& Humaerah, A. M. (2019). Analisis Kandungan Zat Gizi Roti Rumput Laut Lawi-Lawi (Ceulerpa racemosa) Subtitusi Tempe Sebagai Alternatif Perbaikan Gizi Masyarakat. Al-sihah: The Public Health Science Journal, 11(1). 
Sidhi, A. N., Raharjo, M., \& Dewanti, N. A. Y. (2016). Hubungan kualitas sanitasi lingkungan dan bakteriologis air bersih terhadap kejadian diare pada balita di wilayah kerja puskesmas adiwerna kabupaten tegal. Jurnal Kesehatan Masyarakat (e-Journal), 4(3), 665-676.

Winarno, F.G. 1995. Gizi dan Makanan pada Bayi dan Anak. Departemen 